Duthie, E. S. \& LoRenz, L. L. (1952). J. gen. Microbiol. 6, 95-107

\title{
Staphylococcal Coagulase: Mode of Action and Antigenicity
}

\author{
By E. S. DUTHIE AND LISA L. LORENZ \\ The Lister Institute of Preventive Medicine, Elstree, Hertfordshire, and the \\ Pathological Department, Royal South Hants Hospital, Southampton
}

SUMMARY: Different strains of staphylococci vary in ability to produce free coagulase. Methods are given for the selection of suitable strains and for the production and concentration of coagulase from one of them. Of animal plasmas examined, cow, sheep, dog, guinea-pig and mouse showed a relative deficiency in coagulase activator, while plasma of man, monkey, horse, cat, pig, fowl and rabbit contained the most.

Coagulase activator resembles prothrombin closely in physical properties such as thermolability, behaviour during salting out and removal by adsorbents. They are both partly lost in blood clotting and in dicumarol poisoning, but while prothrombin is apparently removed from plasma by repeated Seitz filtration there is no loss of activator. The question of probable identity is discussed.

Antibody to coagulase is present in the sera of many normal individuals and in those suffering from chronic staphylococcal infections. The intramuscular injection of coagulase adsorbed on aluminium phosphate produces similar antibodies in the sera of rabbits.

The marked association between the pathogenicity of staphylococci and their ability to coagulate the plasmas of certain animals has led to a more extensive study of the properties and mode of action of the clotting agent, staphylococcal coagulase, first described by Loeb in 1903 . Two findings in recent years are of especial importance. First, the discovery of Smith \& Hale (1944) that coagulase brought about the clotting of fibrinogen through the agency of a third substance present in the plasma and tissues, and variously termed coagulase activator (Smith \& Hale, 1944), coagulase reacting factor (Tager, 1948a) or coagulase globulin (Miale, 1949). Secondly, the finding that, contrary to earlier observations (Gross, 1931; Walston, 1935; Smith \& Hale, 1944), antibodies against coagulase can in fact be produced (Tager \& Hales, 1948c; Rammelkamp, Hezebicks \& Dingle, 1950).

The work now reported was begun in 1948 with a view to finding whether coagulase was antigenic and if so, how the antigen could be best prepared and administered. During this work various observations were published which tended either to confirm or deny our findings, especially those regarding the nature of coagulase activator. The results now reported may throw some light on these observations, but are preliminary to further studies on the use of coagulase antigen in the production of immunity to staphylococcal infections.

\section{MATERIALS AND METHODS}

Assay of coagulase. Many workers (Lominski \& Roberts, 1946; Tager \& Hales, 1947; Kaplan \& Spink, 1948) measure coagulase by determining the lowest concentration which clots human plasma, usually diluted, after a given 
period of incubation at $37^{\circ}$. More recently, Rammelkamp, Badger, Dingle, Feller \& Hodges (1949), used as the clottable agent a solution of bovine fibrinogen to which a minute amount of human serum was added as activator. In the present work, $0.2 \mathrm{ml}$. volumes of falling dilutions of coagulase in saline buffered to $\mathrm{pH} 7 \cdot 4$, were added to $0.2 \mathrm{ml}$. volumes of $0.1 \%$ human fibrinogen (ether precipitated and dried) containing $5 \%$ rabbit plasma as activator, in tubes measuring $5 \cdot 0 \times \mathbf{0 \cdot 8} \mathrm{cm}$. This amount of rabbit plasma was nearly optimal for the reaction, so that the different amounts of activator present in different batches of fibrinogen could be neglected. The rabbit plasma was stored for months at $-\mathbf{2 0}^{\circ}$ without any loss of activity, and the fibrinogen plasma mixture was likewise stable for a few hours when frozen. The tubes were incubated at $37^{\circ}$ for $30 \mathrm{~min}$. or $1 \mathrm{hr}$; $30 \mathrm{~min}$. was adequate for most purposes. Since the reaction proceeds stoicheiometrically the titre at $1 \mathrm{hr}$. is double that at $30 \mathrm{~min}$. (Tager, $1948 \mathrm{~b}$ ). At the end of 30 or $60 \mathrm{~min}$., as the case may be, one drop $(0.02 \mathrm{ml}$.) of a $1 \%$ aqueous suspension of Supercel (Johns Manville) was added to each tube, and after dispersing the particles of Supercel the rack of tubes was placed in the refrigerator for $20-30 \mathrm{~min}$. Falling dilutions of a standard preparation of coagulase were included in each test, and after further shaking these were matched visually with the unknown. The Supercel particles were found in different degrees of dispersion depending on the amount of coagulation which had occurred in each tube, and differences in flocculation corresponding to $\pm 10 \%$ in the coagulase concentration could be recognized. The M.C.D. or minimal clotting dose was defined as that amount of coagulase $/ \mathrm{ml}$. which, when mixed with $1 \mathrm{ml}$. plasma fibrinogen and incubated for $1 \mathrm{hr}$. at $37^{\circ}$ under the conditions specified, gave just visible flocculation of the particles. Most batches prepared with the 'Newman' strain of Staphylococcus aureus had values of 3000-3500 M.C.D. $/ \mathrm{ml}$.

Assay of coagulase activator; method $A$. In the early stages of the work $0.2 \mathrm{ml}$. volumes of falling dilutions of the solution to be assayed were added to $0.8 \mathrm{ml}$. volumes of buffered saline $(\mathrm{pH} 7 \cdot 4)$ containing $0.2 \%(\mathrm{w} / \mathrm{v})$ of bovine fibrinogen (ether precipitated and dried). These mixtures were held at $37^{\circ}$, and $0.2 \mathrm{ml}$. of coagulase solution was then added, the time of clotting being measured from the time of addition of coagulase. Reference to a curve prepared by diluting a known solution of activator allowed comparisons to be made with the activator content of the solution tested.

Assay of coagulase activator: method B. More recently it has been found possible to measure minimal amounts of activator by adding falling dilutions to tubes containing coagulase and bovine fibrinogen, the former in concentrations insufficient to clot the fibrinogen in the presence of the small amount of bovine activator present in the particular sample. Since a deficiency of activator is compensated for to some extent by an excess of coagulase, traces of activator were easily detected, but for most purposes submaximal amounts of coagulase were sufficient. In practice $\mathbf{0 . 2} \mathrm{ml}$. volumes of falling dilutions of activator in buffer saline were added to $0.2 \mathrm{ml}$. volumes of $0.4 \%$ bovine fibrinogen, followed by $0.2 \mathrm{ml}$. coagulase solution containing as a maximum 3,000 M.c.D. $/ \mathrm{ml}$. After incubation for $1 \mathrm{hr}$. at $37^{\circ}, 0.02 \mathrm{ml}$. of Supercel 
suspension ( $1 \%$ ) was added and the tubes read as in the coagulase assay test.

Assay of antibody. Because of the instability of coagulase at alkaline $\mathrm{pH}$ values, all dilutions were made in a mixture of 1 vol. $\mathrm{m} / \mathbf{1 5}$ phosphate buffer (pH 7.0) and 2 vol. $0.85 \%$ saline. The stock solution of coagulase was the partially purified cadmium precipitated material described later, dissolved at $5 \mathrm{mg} . / 10 \mathrm{ml}$. of $0.01 \mathrm{M}-\mathrm{HCl}$. This solution was diluted immediately before use in buffer saline to give 20 M.C.D. $/ \mathrm{ml}$. Volumes $(0 \cdot 1 \mathrm{ml}$.) of falling dilutions of serum were mixed with equal volumes of the diluted coagulase and were left for $30 \mathrm{~min}$. at room temperature, after which $0 \cdot 2 \mathrm{ml}$. of $0 \cdot 1 \%(\mathrm{w} / \mathrm{v})$ fibrinogen containing $5.0 \%(\mathrm{v} / \mathrm{v})$ rabbit plasma was added to each tube and the mixtures incubated at $37^{\circ}$ for $1 \mathrm{hr}$. Supercel suspension (1\%) was added and the tubes read after $30 \mathrm{~min}$. at $4^{\circ}$. The reciprocal of the serum dilution just sufficient to allow minimal clotting was taken as the titre of the serum expressed in units. A serum of known value was included in all tests for comparison. The sera were not inactivated but were incubated with heparin for a short time to destroy thrombin and were stored frozen if not used immediately. The stability of the coagulase at $\mathrm{pH} \mathbf{7 \cdot 0}$ is less than at $\mathrm{pH} \mathbf{2 \cdot 0}$, but there was no demonstrable loss when equal volumes of coagulase (20 M.C.D. $/ \mathrm{ml}$.) were mixed with either saline or normal rabbit serum diluted $1 / 2$ and allowed to stand for $30 \mathrm{~min}$. at room temperature as in the assay, provided that the final $\mathrm{pH}$ value of the mixture was $\mathbf{7 \cdot 0}$.

\section{EXPERIMENTAL}

\section{Strain selection and production of coagulase}

The coagulase used in these experiments was produced by a strain of Staph. aureus, 'Newman' (NCTC 8178), originally isolated from a case of secondarily infected tubercular osteomyelitis in man. It was the best free-coagulase producer among a large number of staphylococci isolated from human and animal sources; the stability of its coagulase was greater than that of other strains tested. This strain was selected by choosing colonies on nutrient agar plates containing $50 \mathrm{mg}$./human fibrinogen (ether precipitated) and $2.5 \mathrm{ml}$. human plasma $/ 100 \mathrm{ml}$. medium, these components being added to the molten agar immediately before pouring and at a temperature not exceeding $50^{\circ}$. After $18 \mathrm{hr}$. at $37^{\circ}$ suitable colonies were surrounded by a zone of fibrin 2-3 $\mathrm{mm}$. in diameter, which increased in size when the plates were left at room temperature. Many strains showed partial clearing of this zone through the action of either a protease or of staphylokinase, but this did not occur with the 'Newman' strain. Selected colonies were subcultured into $25 \mathrm{ml}$. conical flasks containing about $5 \mathrm{ml}$. nutrient broth. These cultures were grown for about $12 \mathrm{hr}$. at rest and were then agitated for several hours at $37^{\circ}$ until full growth had been reached. The whole cultures and the centrifuged supernatants were then tested for coagulase activity. In the majority of strains the coagulase was about equally divided between cells and supernatant fluid, but in the 'Newman' strain some $90 \%$ of it was in the supernatant. Since the 'Newman' strain was in all respects the most suitable for this study, all work 
henceforth described was done with this strain. It must be emphasized that later work has shown that coagulase from other strains may behave differently.

Using the strain 'Newman', any good digest or infusion broth gave optimal coagulase production at full growth, which could not be enhanced by the use of oxygen and carbon dioxide mixtures or by subsequent autolysis. The 'Casamino acid' medium used by Rogers (1945) gave equally good growth but poor coagulase production. Shaken cultures contained $c .4-5$ times as much coagulase as did unshaken cultures, the amounts being roughly proportional to the amount of growth. For the production of large amounts of coagulase, 21 . conical flasks containing $400 \mathrm{ml}$. broth were heavily seeded with a freshly grown culture and treated in the same manner as the smaller flasks. Since on subculture or storage in media the 'Newman' strain produced occasional variants which were relatively poor coagulase producers, it was important to pick, from time to time, good coagulase-producing colonies from fibrinogen plates.

\section{Table 1. The influence of temperature and $\mathrm{pH}$ on the stability of crude coagulase}

A culture filtrate of high coagulase content was used. The $\mathrm{pH}$ was altered by the addition of dilute $\mathrm{HCl}$ or dilute $\mathrm{NaOH}$. After incubation, all samples were neutralized and tested for coagulase activity.

\begin{tabular}{|c|c|c|c|c|c|c|}
\hline & & \multicolumn{5}{|c|}{ pH value } \\
\hline & & 2 & 4 & 5 & $\gamma$ & 9 \\
\hline Time & & \multicolumn{5}{|c|}{ Loss in coagulase activity (\%) } \\
\hline 2 & $37^{\circ}$ & 0 & 50 & 0 & 0 & 20 \\
\hline 2 & $60^{\circ}$ & 20 & 90 & 95 & 60 & 70 \\
\hline 1 & $100^{\circ}$ & 100 & 100 & 100 & 100 & 100 \\
\hline
\end{tabular}

\section{Concentration of coagulase}

For sterilization and concentration advantage was taken of the marked stability of coagulase at $\mathrm{pH} 2$ (Table 1). Bacteria were removed from the culture by mixing with 'Filter cel' and filtration through paper, after which the filtrate containing the coagulase was cooled and all subsequent manipulations carried out at $4^{\circ}$. Cadmium sulphate was added to a final concentration of $0 \cdot 5 \%(\mathrm{w} / \mathrm{v})$ and the mixture adjusted to $\mathrm{pH} \mathbf{5 \cdot 8}$. The flocculant precipitate was collected next day and dissolved by the gentle addition of $\mathrm{N}-\mathrm{HCl}$ to a final $\mathrm{pH}$ value of $c . \mathbf{2 \cdot 0}$. This solution was dialysed against running tap water at $\mathrm{pH} \mathbf{2 \cdot 0}$ until free from cadmium, insoluble material was removed, the preparation lyophil dried. The total loss was about $10 \%$.

\section{Properties of the coagulase preparation}

In agreement with Tager $(\mathbf{1 9 4 8} b)$, we found that coagulase was rapidly destroyed by proteolytic enzymes; as little as 1 part of crystalline trypsin in $10^{8}$ of solution was able to destroy 3000 M.c.D. in $4 \mathrm{hr}$. at $37^{\circ}$. Partially purified coagulase material had an activity of 6000 M.C.D./mg.; it contained c. $60 \%$ protein, so that its activity was 10,000 M.C.D./mg. protein. Its most 
remarkable property was its stability at $\mathrm{pH} \mathbf{2 \cdot 0}$, there being little destruction in several hours at $56^{\circ}$ when held at this $\mathrm{pH}$. A solution of $1 \mathrm{mg} . / \mathrm{ml}$. had no action on rabbit cells or guinea-pig skin, and did not liquefy a fibrin clot in $24 \mathrm{hr}$. at $37^{\circ}$. It had slight phosphatase activity and $1 \mathrm{mg}$. destroyed 30 units of penicillin in $1 \mathrm{hr}$. at $37^{\circ}$.

\section{Occurrence of coagulase activator}

Assay method B enabled us to compare the concentration of coagulase activator present in the various plasmas. The animals so far examined fell into two well-marked groups: human, monkey, horse, cat, pig, fowl and rabbit plasmas showed clotting at final dilutions of $1 / 150,000$ to $1 / 200,000$, while cow, sheep, dog, guinea-pig and mouse plasmas reacted at final dilutions of $1 / 3,000$ to $1 / 10,000$. A comparison of the plasmas of a number of individual members of each species showed little or no variation from the figures given.

\section{Comparison of coagulase activator and prothrombin}

Since the first description of coagulase activator by Smith \& Hale (1944), various authors (Tager \& Hales, $1948 a$; Tager, 1948 $b$; Kaplan \& Spink, 1948) have studied the occurrence of activator in human and other plasmas, bearing in mind its possible identity with one of the known plasma components. Tager \& Hales (1948a), using human plasma, noted a similarity in properties between activator and prothrombin, but because of certain discrepancies they did not conclude that the two were identical. The most important separation of activator and prothrombin appeared on repeated Seitz filtration of human plasma, the filtrate showing no loss of activator but failing to clot on re-calcification and addition of thromboplastin. Nevertheless, some prothrombin was left, since Tager \& Hales found that acid precipitation of this filtrate, following dilution in distilled water according to Mellanby's method (1930), showed prothrombin to be present in small amounts in the globulin precipitate.

The question is further complicated by discrepancies arising out of the study of plasma fractions obtained by $\left(\mathrm{NH}_{4}\right)_{2} \mathrm{SO}_{4}$ precipitation and by ethanol precipitation in the cold at controlled ionic and $\mathrm{H}$-ion concentrations (Cohn, Strong, Hughes, Mulford, Ashworth, Melin \& Taylor, 1946). Results obtained by different authors are summarized below:

Fraction containing coagulase activator after

Author
Tager (1948a)
Kaplan \& Spink (1948)
Miale (1949)
Gerheim, Ferguson \&
Travis (1947)

\begin{tabular}{|c|c|}
\hline$\left(\mathrm{NH}_{4}\right)_{2} \mathrm{SO}_{4}$ precipitation & Ethanol precipitation \\
\hline Globulin at $40-50 \%$ saturation & $\begin{array}{l}\text { Fractions III-1, IV-2, } \\
\text { IV-1. }\end{array}$ \\
\hline Albumin at $80-100 \%$ saturation & $\begin{array}{l}\text { Fractions IV-4 and } \\
\text { little in V }\end{array}$ \\
\hline $\begin{array}{l}\text { Albumin at } 100 \% \text { saturation } \\
\text { Albumin }\end{array}$ & Fraction IV-4 and IV-1 \\
\hline
\end{tabular}

It is interesting that all the ethanol fractions which show activity are globulin fractions, although three of the above workers found that activator 
occurred with the albumin in $\left(\mathrm{NH}_{4}\right)_{2} \mathrm{SO}_{4}$ fractionation. From the work of Cohn et al. it is known that most of the prothrombin is in fraction IV-2. In our own studies prothrombin was measured by a one-stage technique similar to that of Quick (1942), factor $V$ being added to the mixtures when necessary.

Comparison of plasma and serum. Before reading the papers of the abovementioned authors our attention had been drawn to the possibility that coagulase activator was related to prothrombin by the observation that both human and rabbit plasma contained much more activator than did the corresponding sera, as shown by a comparison of the two at various dilutions (Table 2).

\section{Table 2. Comparison of activator content of rabbit serum and plasma}

Serial dilutions (in saline and buffer, $\mathrm{pH} \mathrm{7 \cdot 4}$ ) of serum and plasma from the same rabbit were tested against coagulase for the presence of activator, using method $\mathbf{A}$.

\begin{tabular}{lrrrr} 
Dilution & \multicolumn{4}{c}{ Clotting time } \\
\cline { 2 - 5 } $1 / 1$ & $\begin{array}{c}\text { Serum } \\
\text { min. }\end{array}$ & $\begin{array}{c}\text { Hec. } \\
\text { Heparinized } \\
\text { plasma } \\
\text { min. }\end{array}$ \\
$1 / 2$ & 2 & 52 & 2 & 40 \\
$1 / 4$ & 3 & 54 & 2 & 40 \\
$1 / 8$ & 5 & 58 & 2 & 38 \\
$1 / 16$ & 7 & 40 & 2 & 40 \\
$1 / 32$ & 11 & 30 & 2 & 20 \\
$1 / 64$ & 14 & 45 & 2 & 35 \\
$1 / 128$ & 19 & 10 & 2 & 45 \\
$1 / 256$ & 25 & - & 3 & 15 \\
$1 / 512$ & 31 & - & 3 & 58 \\
& 45 & - & 4 & 38
\end{tabular}

Destruction by thromboplastin. In the experiment shown in Table 3, mixture A consisted of fresh plasma with brain thromboplastin and free calcium, while mixture B contained plasma and thromboplastin but no free calcium. After incubation the prothrombin concentrations in both mixtures were estimated by a modified one-stage technique, fibrinogen, thromboplastin and calcium being added in the quantities shown in the third column of Table 3. Activator content was measured by method B. As will be seen, mixture $\mathbf{A}$, which contained free calcium, showed almost complete loss of coagulase and activator, but there was little or no loss in mixture $\mathbf{B}$. In this experiment the free calcium both in mixture $A$ and in the subsequent prothrombin estimations was between 2.5 and $3.5 \mathrm{~mm}$., and in the prothrombin dilution curves from which the prothrombin loss was estimated both calcium and factor $\mathrm{V}$ levels were optimum. Nevertheless, the losses given are only approximations. A similar destruction of both prothrombin and activator occurred with Russell's viper venom.

Dicumarol. Rabbits poisoned with dicumarol showed a marked decrease in the activator and prothrombin contents of their plasma, the decreases being approximately the same; similar decreases were found in the plasmas of patients under dicumarol therapy. 
Table 3. Comparison of loss of coagulase activator and prothrombin in plasma incubated with thromboplastin in the presence of calcium ion (mixture $A$ ), and in the absence of calcium ion (mixture $B$ ). Plasma separated from 9 vol. human blood +1 vol. 100 mM. potassium oxalate

\begin{tabular}{|c|c|c|c|}
\hline \multirow[b]{2}{*}{ Mixture A (Ca present) } & Prothrombin test mixture & $\begin{array}{c}\text { Prothrombin } \\
\text { loss }\end{array}$ & $\begin{array}{l}\text { Activator } \\
\text { loss }\end{array}$ \\
\hline & & & \\
\hline $\left.\begin{array}{l}0.4 \mathrm{ml} \text {. plasma } \\
0.2 \mathrm{ml} \text { brain extract } \\
0.2 \mathrm{ml} . \mathrm{CaCl}_{2} 37 \mathrm{~mm} . \\
\text { Incubated } 1 \mathrm{hr} ., 37^{\circ}\end{array}\right\}$ & $\begin{array}{l}0.1 \mathrm{ml} . \text { mixture } \mathrm{A} \\
0.1 \mathrm{ml} \text {. human fibrinogen }(0.4 \%) \\
0.1 \mathrm{ml} . \text { brain extract } \\
0.1 \mathrm{ml} .7 \mathrm{mM} . \mathrm{CaCl}_{2} \\
\text { Clotting time } 4 \mathrm{~min} 30 \text { sec. }\end{array}$ & $\begin{array}{c}- \\
\text { About } 99 \% \\
- \\
-\end{array}$ & $\begin{array}{c}-\overline{-} \\
\text { About } 96 \% \\
- \\
-\end{array}$ \\
\hline Mixture B (Ca absent) & & & \\
\hline $\left.\begin{array}{l}0.4 \mathrm{ml} \text {. plasma } \\
0.2 \mathrm{ml} \text { brain extract } \\
0.2 \mathrm{ml} . \text { saline } \\
\text { Incubated } 1 \mathrm{hr} ., 37^{\circ}\end{array}\right\}$ & $\begin{array}{l}0 \cdot 1 \mathrm{ml} \text {. mixture } \mathrm{B} \\
0 \cdot 1 \mathrm{ml} \text {. human fibrinogen }(0.4 \%) \\
0 \cdot 1 \mathrm{ml} \text {. brain extract } \\
0 \cdot 1 \mathrm{ml} .20 \mathrm{mM}^{-}-\mathrm{CaCl}_{2} \\
\text { Clotting time } 20 \mathrm{sec}\end{array}$ & $\begin{array}{c}- \\
\text { Nil } \\
-\end{array}$ & $\begin{array}{l}- \\
\text { Nil } \\
-\end{array}$ \\
\hline
\end{tabular}

$\left(\mathrm{NH}_{4}\right)_{2} \mathrm{SO}_{4}$ fractionation. A reinvestigation of the fractions obtained with ammonium sulphate confirmed the findings of Tager (1948a); all of the activator was found in the globulin fraction and was precipitated almost completely by $60 \%$ saturation with ammonium sulphate. The prothrombin loss was apparently greater than that of the activator and probably occurred during the subsequent dialysis of the fractions against citrate-saline, a procedure not necessary for the measurement of activator.

Seitz filtration. Repeated Seitz filtration of plasma removed prothrombin without comparable loss of activator. In the cases of human plasma there was an apparent increase of the latter as noted by Tager \& Hales $(1948 a)$. Like these authors, we found that although this filtered plasma was apparently free from prothrombin, the precipitate obtained when it was diluted with distilled water and precipitated at $\mathrm{pH} \mathbf{5 \cdot 0}$, when redissolved, clotted on addition of $\mathrm{CaCl}_{2}$. If this were due to prothrombin in the filtrate, then its activity was less than $1 \%$ of that present in the original plasma.*

Purification by adsorption. Like prothrombin, coagulase activator is readily adsorbed from plasma by barium sulphate or freshly prepared aluminium hydroxide; a specimen of dried purified prothrombin prepared by Dr Rosemary Biggs (by adsorption of fresh human plasma with $\mathrm{C} \alpha$ alumina followed by elution) was found to function well as coagulase activator at very high dilutions. This protein was used in the experiments shown in Table 4, in which the minimal amount of activator needed to produce flocculation of fibrinogen was measured for falling concentrations of coagulase using coagulase assay method B. Thus at 16,000 M.C.D. coagulase $/ \mathrm{ml}$. a final dilution of $1 / 10^{8}$ of purified prothrombin (measured as protein) was sufficient. Lower concentrations of coagulase required more activator, but no simple relationship was found between the coagulase and activator concentrations required, and their product increased as the coagulase concentrations fell.

* The studies of Koller, Loeliger \& Duckert (1951) now make it doubtful if Seitz filtered plasma is always free of prothrombin. 
Table 4. Concentration of activator required to produce minimal clotting for decreasing concentrations of coagulase (Method B)

$\begin{array}{cc}\begin{array}{c}\text { Coagulase } \\ \text { concentration } \\ \text { added }\end{array} & \begin{array}{c}\text { Activator } \\ \text { concentration } \\ \text { added }\end{array} \\ \text { (M.C.D./ml.) } & \text { (mg. protein } / \text { ml. }) \\ \left(\times 10^{-6}\right)\end{array}$

Stability. We investigated the stability of activator and prothrombin in rabbit plasma kept at different $\mathrm{pH}$ values and temperatures (Table 5). There was marked loss of both components at the acid and alkaline values except at $60^{\circ}$, where both were most stable at the acid level. The $30 \mathrm{~min}$. value at $60^{\circ}$ is not given, since the loss was complete in all cases. In spite of possible errors due to the approximate nature of the measurements, there was surprisingly good agreement between the stability of the two substances in the range investigated.

Table 5. The influence of heat at different $\mathrm{pH}$ values on rabbit activator and rabbit prothrombin using rabbit plasma (diluted 1/4)

Factor $\mathrm{V}$ added in all prothrombin estimations. Activator measured by method $\mathbf{A}$.

\begin{tabular}{|c|c|c|c|c|c|c|c|}
\hline \multirow{2}{*}{$\begin{array}{l}\text { Time } \\
\text { (min.) }\end{array}$} & \multirow{2}{*}{ Temp. } & \multirow{2}{*}{$\begin{array}{l}\text { pH 4 } \\
\text { Residual }\end{array}$} & \multirow{2}{*}{\multicolumn{2}{|c|}{$\begin{array}{l}\mathrm{pH} 7 \quad \mathrm{pH} 11 \\
\text { activator (\%) }\end{array}$}} & \multirow{2}{*}{\multicolumn{3}{|c|}{$\underset{\text { Residual prothrombin (\%) }}{\text { pH 4 }} \underset{\text { pH } 7}{\text { pH 11 }}$}} \\
\hline & & & & & & & \\
\hline 30 & $\mathbf{2 5}^{\circ}$ & 15 & 100 & 60 & 14 & 100 & 75 \\
\hline 30 & $37^{\circ}$ & $\mathbf{3}$ & 100 & 8 & 5 & 100 & 4 \\
\hline 10 & $60^{\circ}$ & 12 & $0 \cdot 1$ & $0 \cdot 1$ & 15 & Nil & Nil \\
\hline
\end{tabular}

Coagulase clotting. Both Smith \& Hale (1944), using testis extract as activator, and Miale (1949), using the albumin fraction of plasma, found that the incubation of coagulase and activator brought about the formation of a thrombin-like product, as shown by a progressive decrease in the clotting time when samples of the mixture were taken at intervals and added to fibrinogen. We found that this phenomenon is only apparent at certain dilutions of both coagulase and activator (Table 6), using as activator the purified prothrombin preparation previously mentioned. In this experiment prior incubation of 300 M.C.D. coagulase $/ \mathrm{ml}$. with all of the activator dilutions gave shorter clotting times than in the controls, but this was not found with the lower coagulase value. In a previous report (1950), based on experiments made with human plasma, we stated that coagulase was lost during clotting; this does not occur with rabbit plasma, and it is therefore likely that the loss we then found was due to the presence of an inhibitor in the human plasma used. With rabbit plasma we were likewise unable to demonstrate any loss in either prothrombin or activator during coagulase clotting, but it is possible 
that the loss is less than can be.detected by the methods used. If coagulase activator is identical with prothrombin, then the thrombin-like product is not thrombin, since it is not inhibited by heparin.

\section{Serum inhibition}

A number of workers (Lominski \& Roberts, 1946; Bekker, 1947; Tager \& Hales, 1948b; Rammelkamp et al. 1950) have noted the presence of a coagulase inhibitor in the plasma of certain normal humans, while Kaplan \& Spink (1948) and Gerheim \& Ferguson (1949) found a coagulase inhibitor in the sera of other animals. Lominski \& Roberts detected inhibition in just over $50 \%$ of all human sera examined, while Tager \& Hales found only $7 \%$ of all human plasmas to be devoid of inhibitor.

Human sera. Since the proportion of sera from normal humans showing antibodies to coagulase will depend on the sensitivity of the method used, it was of interest to measure some normal levels by the present method. The sera of twenty-five members of the laboratory staff showed the following distribution of antibodies : $\operatorname{six}=$ nil; four $=0-1 \mathrm{unit} / \mathrm{ml}$; ten $=2-10 \mathrm{units} / \mathrm{ml}$.; two $=10-20$ units $/ \mathrm{ml}$.; two $=20-25$ units $/ \mathrm{ml}$.; and one $=60$ units $/ \mathrm{ml}$. In this small series there was no clear association between past staphylococcal infection and the presence of antibodies. Sera from cases of chronic deep-seated staphylococcal infections all showed high anticoagulase titres, 100 units $/ \mathrm{ml}$. being present in some cases.

Artificial immunization. Washed aluminium phosphate suspension (6 mg./ ml.) prepared according to the method of Holt (1950) adsorbed up to $3.5 \mathrm{mg}$. coagulase/mg. aluminium phosphate at $\mathrm{pH} 4.8$ from a $1 \%$ solution of the partly purified coagulase. This material gave higher and more constant levels of anticoagulase in the sera of rabbits when injected either intramuscularly or subcutaneously, than did injections of coagulase alone, and was used in all the later experiments. The experiment shown in Table 7 was one of a series designed to find the optimal amounts of both aluminium phosphate and coagulase required. In this instance an increase in the amount of coagulase injected was not accompanied by an increase in the titre reached 14 days after the final injections. Nevertheless, all animals responded; four animals gave 5 units $/ \mathrm{ml}$. after one injection, and two reached 20 units $/ \mathrm{ml}$. $14 \mathrm{~d}$. ys after the third injection of $2 \mathrm{mg}$. coagulase. The highest titre so far reached was 40 units/ $\mathrm{ml}$. following 3 injections over 6 weeks of larger amounts of more impure coagulase.

\section{DISCUSSION}

The many conflicting reports in the literature on the properties of staphylococcal coagulase are in part due to the use of totally different strains of staphylococci grown on different media. Whereas it is usual to use coagulase which has been separated from the cells by filtration or centrifugation, some authors have used suspensions of living or of heat-killed organisms, and this in our experience will affect the results. Furthermore, as Tager (1948b) showed, a highly purified coagulase may exhibit qualities different from those of the 
Table 6. Decrease in clotting time following prior incubation of equal volumes of coagulase and purified activator (titre $1 / 60,000)$ at $37^{\circ}$ for 30 min.

\begin{tabular}{|c|c|c|c|c|c|c|c|c|c|c|c|c|c|c|c|c|c|c|c|c|}
\hline \multirow{3}{*}{$\begin{array}{l}\text { Coagulase } \\
\text { (M.C.D./ml.) }\end{array}$} & \multicolumn{10}{|c|}{ Incubated } & \multicolumn{10}{|c|}{ Non-incubated control } \\
\hline & \multicolumn{2}{|c|}{$1 / 100$} & \multicolumn{2}{|c|}{$1 / 500$} & \multicolumn{2}{|c|}{$1 / 1000$} & \multicolumn{2}{|c|}{$1 / 2000$} & \multicolumn{4}{|c|}{$\begin{array}{c}1 / 4000 \quad 1 / 100 \\
\text { Clotting time }\end{array}$} & \multicolumn{2}{|c|}{$1 / 500$} & \multicolumn{2}{|c|}{$1 / 1000$} & \multicolumn{2}{|c|}{$1 / 2000$} & \multicolumn{2}{|c|}{$1 / 4000$} \\
\hline & $\begin{array}{c}\min . \\
18\end{array}$ & $\begin{array}{c}\text { sec. } \\
-\end{array}$ & min. & $\begin{array}{c}\text { sec. } \\
\mathbf{3 0}\end{array}$ & $\underset{22}{\min }$ & $\begin{array}{c}\text { sec. } \\
45\end{array}$ & $\begin{array}{c}\min . \\
42\end{array}$ & $\begin{array}{c}\text { sec. } \\
45\end{array}$ & $\underset{78}{\min }$ & $\begin{array}{r}\text { sec. } \\
-\end{array}$ & $\begin{array}{c}\min . \\
20\end{array}$ & $\begin{array}{r}\text { sec. } \\
\mathbf{3 0}\end{array}$ & $\begin{array}{c}\text { min. } \\
25\end{array}$ & $\begin{array}{l}\text { sec. } \\
-\end{array}$ & min. & $\begin{array}{c}\text { sec. } \\
40\end{array}$ & min. & $\begin{array}{c}\text { sec. } \\
\mathbf{3 0}\end{array}$ & $\begin{array}{c}\min . \\
93\end{array}$ & $\begin{array}{r}\text { sec. } \\
-\end{array}$ \\
\hline 75 & 39 & 40 & 51 & 35 & 47 & 40 & 78 & - & 129 & - & 33 & 40 & 41 & $\mathbf{3 0}$ & 78 & - & 78 & - & - & 一 \\
\hline
\end{tabular}

Table 7. Production of anticoagulase in rabbits using coagulase adsorbed on $\mathrm{AlPO}_{4}$. Injections given on 1 st, 15 th and 29th days of experiment

\begin{tabular}{|c|c|c|c|c|c|c|c|c|c|c|c|c|c|c|c|}
\hline \multirow{2}{*}{\multicolumn{2}{|c|}{ Dosage (mg.) }} & \multicolumn{4}{|c|}{ Day 14} & \multicolumn{4}{|c|}{ Day 28} & \multicolumn{6}{|c|}{ Day 42} \\
\hline & & \multicolumn{14}{|c|}{ Serum dilution } \\
\hline $\mathrm{AlPO}_{4}$ & Coagulase & 1 & $2 \frac{1}{2}$ & 5 & 10 & 1 & $2 \frac{1}{2}$ & 5 & 10 & 1 & $2 \frac{1}{2}$ & 5 & 10 & 20 & 30 \\
\hline & & \multicolumn{14}{|c|}{ Degree of clotting* } \\
\hline $\mathbf{3}$ & 2 & - & - & \pm & + & - & - & - & + & - & - & - & - & + & ++ \\
\hline 3 & 2 & - & \pm & $\bar{t}$ & ++ & - & - & - & + & - & - & - & - & \pm & + \\
\hline $\mathbf{3}$ & 4 & - & $=$ & \pm & + & - & - & \pm & $\bar{t}$ & - & - & + & $+t$ & ++ & ++ \\
\hline $\mathbf{3}$ & 4 & ++ & ++ & ++ & ++ & - & \pm & ++ & ++ & - & + & ++ & ++ & ++ & $+t$ \\
\hline $\mathbf{3}$ & 8 & - & - & + & ++ & - & $=$ & + & ++ & - & - & - & + & ++ & ++ \\
\hline $\mathbf{3}$ & 8 & - & - & \pm & + & - & - & \pm & + & - & - & - & + & ++ & ++ \\
\hline $\mathbf{0}$ & $\mathbf{0}$ & ++ & ++ & ++ & ++ & ++ & ++ & ++ & $+t$ & ++ & ++ & ++ & $+t$ & ++ & ++ \\
\hline
\end{tabular}

* Full clotting $=++$; intermediate clot $=+$ or \pm ; no clot $=-$; serum samples tested day before second and third injections and 13 days after last injection. 
crude culture filtrate. We have now found other strains which produce large amounts of extracellular coagulase with properties somewhat different from the coagulase produced by the 'Newman' strain.

Our experiments indicate a similarity between the properties of coagulase activator and prothrombin; because of the role of the latter in normal clotting it is tempting to consider that they may be identical. We find that they are similar in physical behaviour; both are partly lost in normal clotting and on incubation with thromboplastin in the presence of $\mathrm{Ca}$ ion, and they both decrease in concentration almost pari passu in dicumarol poisoning. A similar decrease has recently been found in a case of obstructive jaundice, where both activator and prothrombin levels were diminished to $25 \%$ of normal. The work of other workers with ethanol precipitated fractions not available to us shows a wider spread of activator than of prothrombin over the various fractions. Contrary to several of these workers, we were unable to find activator in the albumin fraction following $\left(\mathrm{NH}_{4}\right)_{2} \mathrm{SO}_{4}$ precipitation, but in the globulin fractions it occurred in the same fraction as the prothrombin. The chief point of difference between activator and prothrombin in our work (cf. Tager \& Hales, 1948a) was the complete loss of prothrombin in plasma on repeated Seitz filtration, without any apparent loss of activator. It is conceivable that repeated Seitz filtration, while not removing prothrombin, may so alter it that although it is no longer capable of being converted into thrombin, it may yet function as coagulase activator. Since acid precipitation of this apparently prothrombin-free plasma can restore a fraction of its former activity, we cannot assume that prothrombin is ever completely absent following repeated Seitz filtration, and a physical change in its structure is therefore a possibility. Should prothrombin and activator be identical, it is not remarkable that the prothrombin of one species should be susceptible and the prothrombin of another refractory to the action of staphylococcal coagulase, since species specificity is a common occurrence in the case of most known toxins.

Both Smith \& Hale (1944) and Miale (1949) produced evidence that the incubation of coagulase and activator leads to the production of a thrombinlike product, as shown mainly by a progressive shortening in clotting time of the mixture when added to guinea-pig plasma or bovine fibrinogen. Our results show such a shortening at the higher coagulase concentration tested, and the increase noted at the lower level may be due to the instability of low concentrations of coagulase when held for any period at $37^{\circ}$. Further evidence (Miale, 1949), that the thrombin-like product is more unstable when heated at $60^{\circ}$ for $30 \mathrm{~min}$. than coagulase or coagulase activator alone, is not borne out by our work, since we find that activator is rapidly changed at this temperature, and one may therefore expect a similar thermolability of any thrombin-like product formed by a union of the two.

It is evident from our results and those of Tager \& Hales (1948c), that while antibodies may be produced in rabbits by successive injections of coagulase, the dose required is high and needs to be supplemented with $\alpha$-lysin or to be adsorbed on a suitable carrier. Failure to use large doses, together with an adjuvant such as aluminium phosphate, probably accounts for the failure of 
other investigators to produce antibodies in rabbits. Our own experience indicates that an immunity comparable to that found in the sera of humans suffering from staphylococcal infections may be reached in rabbits after three intramuscular injections.

We desire to thank Dr C. H. Lack for numerous staphylococcal strains and sera; Dr R. A. Kekwick, Miss M. Mackay and Dr J. W. Lyttleton for preparations of fibrinogen; and Prof. E. B. Chain in whose department at the Istituto Superiore de Sanitá, Rome, the senior author prepared the partially purified coagulase used. In addition, the senior author is indebted to the South West Regional Metropolitan Hospital Board for a research grant which enabled him to extend and complete these studies, and to Miss Sheila Isherwood for valuable technical assistance.

\section{REFERENCES}

Bekker, J. H. (1947). Studies on staphylocoagulase. II. Antistaphylocoagulase in human serum. Antonie van Leeurenhoek J. Microbiol. Serol. 13, 128.

Cohn, E. J., Strong, L. E., Hughes, W. L. jun., Mulford, D. J. Ashworth, J., Meisn, M. \& TAYLOR, H. L. (1946). Preparation and properties of serum and plasma proteins. IV. A system for the separation into fractions of the protein and lipoprotein components of biological tissues and fluids. J. Amer. chem. Soc. 68,459 .

Duthie, E. S. \& LoRenz, L. (1950). Staphylococcal coagulase: the nature of plasma activator in the clotting process. Nature, Lond. 165, 729.

Gerheim, E. B., Ferguson, J. H. \& Travis, B. L. (1947). Activation of staphylocoagulase. Proc. Soc. exp. Biol., N.Y. 66, 525.

Gerherm, E. B. \& Ferguson, J. H. (1949). Staphylocoagulation in plasmas of various animal species. Proc. Soc. exp. Biol., N.Y. 71, 258.

Gross, H. (1931). Der Plasmagerinnungsstoff der Staphylokokken. Z Zbl. Bakt. (1. Abt. Orig.) 122, 354.

Holt, L. B. (1950). Developments in Diphtheria Prophylaxis. London: Heinemann.

Kaplan, M. H. \& SpINK, W. W. (1948). Studies of the staphylocoagulase reaction: nature and properties of a plasma activator and inhibitor. Blood, 3, 573.

Koller, F., Loeliger, A. \& Duckert, F. (1951). Experiments on a new clotting factor (Factor vir). Acta Haemat. 6, 1.

LOEB, L. (1903). The influence of certain bacteria on the coagulation of the blood. J. med. Res. 10, 407 .

Lominski, I. \& RoBerts, G. B. (1946). A substance in human serum inhibiting staphylocoagulase. J. Path. Bact. 58, 187.

Mellanby, J. (1930). Prothrombase-Its preparation and properties. Proc. Roy. Soc. B, 107, 271.

Miale, J. B. (1949). The role of staphylocoagulase in blood coagulation. I. The reaction of staphylocoagulase with coagulase-globulin (CG) to form coagulasethrombin (CT). Blood, 4, 1039.

QuIck, A. J. (1942). The Haemorrhagic Diseases. Springfield, Illinois: Hoeber.

Rammelkamp, C. H., Badger, G. F., Dingle, J. H., Feller, A. E. \& Hodges, R. G. (1949). A quantitative method for measuring staphylococcal anticoagulase. Proc. Soc. exp. Biol., N.Y. 72, 210.

Rammelkamp, C. H., Hfizebicks, M. M. \& Dingle, J. H. (1950). Specific coagulases of staphylococcus aureus. J. exp. Med. 91, 295.

ROGERS, J. H. (1945). The conditions controlling the production of hyaluronidase by micro-organisms grown in simplified media. Biochem. J. 39, 435.

SMTTH, W. \& HALE, J. H. (1944). The nature and mode of action of staphylococcus coagulase. Brit. J. exp. Path. 25, 101. 
TAger, M. (1948a). Studies on the coagulase-reacting factor. I. The reaction of staphylocoagulase with the components of human plasma. Yale J. Biol. Med. 20, 369.

TAGER, M. (1948b). Concentration, partial purification, properties and nature of staphylocoagulase. Yale J. Biol. Med. 20, 487.

Tager, M. \& Hales, H. (1947). Quantitative coagulase and toxin production by staphylococci in relation to the clinical source of the organisms. Yale J. Biol. Med. 20, 41.

TAger, M. \& Hales, H. (1948a). Studies on the coagulase-reacting factor. II. Properties of coagulase reacting factor and relation to blood-clotting components. J. Immunol. 60, 1.

TAGER, M. \& Hales, H. (1948b). Differences in the resistance of human plasmas to staphylocoagulase. Yale J. Biol. Med. 21, 91.

Tager, M. \& Hales, H. (1948c). The experimental production of antibodies to staphylocoagulase. J. Immunol. 60, 475.

Walston, H. D. (1935). The clotting of plasma through staphylococci and their products. J. Hyg., Camb. 35, 549.

(Received 18 July 1951) 